\title{
Predictors of Mortality among TB-HIV Co-Infected Children Attending Anti-Retroviral Therapy Clinics of Selected Public Hospitals in Southern, Ethiopia: Retrospective Cohort Study
}

Jifare Gemechu

Wachemo University

Bereket Gebremichael

Addis Ababa University

Tewodros Tesfaye

Addis Ababa University

Alula Seyum

Wachemo University

Desta Erkalo ( $\sim$ erkde12@gmail.com )

Wachemo University https://orcid.org/0000-0001-5981-439X

\section{Research}

Keywords: TB-HIV/AIDS, Mortality, Children, Anti-Retroviral Therapy

Posted Date: July 19th, 2021

DOl: https://doi.org/10.21203/rs.3.rs-704349/v1

License: (c) (1) This work is licensed under a Creative Commons Attribution 4.0 International License. Read Full License

Version of Record: A version of this preprint was published at Archives of Public Health on January 4th, 2022. See the published version at https://doi.org/10.1186/s13690-021-00713-1. 


\section{Abstract}

Background: Co-infection of tuberculosis and HIV has a significant impact on public health. TB is the most common opportunistic infection and the leading cause of death in HIV-positive children worldwide. But there is paucity of studies concerning the predictors of mortality among TB-HIV co-infected children. This study aimed to determine the predictors of mortality among TB-HIV co-infected children attending ART clinics of public hospitals in Southern Nation, Nationalities and Peoples Region (SNNPR), Ethiopia.

Methods: A hospital-based retrospective cohort study design was used among 284 TB-HIV co-infected children attending ART clinics at selected public hospitals in SNNPR, Ethiopia, from January 2009 to December 2019. Then, medical records of children who were TB/HIV co-infected and on ART were reviewed using a structured data extraction tool. Data were entered using Epidata 4.6 and analyzed using SPSS version 23. The Kaplan Meier survival curve along with log rank tests was used to estimate and compare survival time. Bivariable and multivariable analyses were conducted to identify predictors of mortality among TB/HIV co-infected children. Adjusted Hazard Ratio with p value $\leq 0.05$ and $95 \%$ confidence interval was considered statistically significant.

Result: A total of 284 TB/HIV co-infected children were included in the study. Among these, 35 (12.3\%) of them died during the study period. The overall mortality rate was $2.78(95 \% \mathrm{Cl}=1.98-3.99)$ per 100 child years of observation. The predictors of mortality were anemia (AHR=3.6; $95 \% \mathrm{Cl}: 1.39-9.31$ ), fair or poor ART drug adherence (AHR=2.9; 95\% Cl=1.15-7.43), extra pulmonary TB (AHR=3.9; 95\%Cl: 1.34-11.45) and TB drug resistance (AHR=5.7; 95\% Cl: 2.07-15.96).

Conclusion: Mortality rate of TB/HIV co-infected children in selected public hospitals in SNNPR, Ethiopia was documented as 2.78 per child years of observation as a result of this study. Moreover, Anemia, drug resistant tuberculosis, extra pulmonary TB and poor adherence to ART drugs were identified as the predictors of mortality among these children.

\section{Background}

Tuberculosis (TB) is a chronic communicable bacterial infection caused primarily by Mycobacterium tuberculosis and occasionaly by Mycobacterium africanum, Mycobacterium canetti, or Mycobacterium bovis(1). It mainly affects the lungs (pulmonary TB), but it can sometimes affect other sites, which is known as extra pulmonary TB. It is spread through inhalation of mucus droplets when an infected person coughs or sneezes and releases bacteria into the air. Usually, the clinical manifestation in children is nonspecific. However, the most common symptoms include a non-productive cough, a fever lasting more than two weeks, weight loss, night sweats, loss of appetite, and decreased activity. Whereas the symptom of extra pulmonary TB is dependent on the site affected (2).

People with compromised immune systems, such as those suffering from human immunodeficiency virus (HIV), malnutrition, or diabetes mellitus (DM), are at a higher risk of developing the disease. Almost all HIV-positive people and $40 \%$ of HIV-negative people with tuberculosis who do not receive effective 
treatment will die (3). HIV destroys and damages immune cells, resulting in immunodeficiency. This immunodeficiency increases susceptibility to diseases such as tuberculosis $(3,4)$.

TB/HIV co-infection poses a challenge to human survival because of the mutual impact. HIV complicates each aspect of TB including presentation, diagnosis, and treatment(5). As the viral load rises, tuberculosis speeds up the progression of HIV infection to AIDS and consequently, leads to death. On the other hand, HIV infection reduces the CD4 count leading to depressed immunity through which it enhances the activation of latent TB and increases the relapse rate of TB. Their combination increases the burden on the health system, the development of extra pulmonary TB and negative sputum smears(1).

Treatment of HIV/TB co-infected patients may result in difficulties such as drug interactions, toxicity, immunological reconstitution inflammatory syndrome (IRIS), and decreasing plasma drug level, leading to drug resistance treatment regardless of adherence. TB may potentially be over diagnosed in HIVinfected children due to the presence of various illnesses that mimic TB (5). The diagnosis of tuberculosis in HIV-infected children may be problematic due to the absence of tuberculin skin test reactivity, the difficulties of culture confirmation, and the clinical similarities of TB to many other HIVrelated infections (2).

The disease burden obviously varies among countries, ranging from less than five to more than 500 new cases per 100,000 population per year, with a global average of 130 . The majority of the TB cases in the aforementioned study occurred in the WHO regions of Asia, Africa, and the Western Pacific, accounting for $44 \%, 24 \%$, and $18 \%$, respectively $(6,7)$. According to the 2018 report of the joint United Nations program on HIV and AIDS (UNAIDS), 37.9 million people worldwide are infected with HIV. Among these, 1.7 million are children $<15$ years and estimated 84,000 newly infected children are living in eastern and southern Africa (8).

In 2018, people living with HIV accounted for an estimated 8.6 percent of all incident TB cases. The proportion of TB/HIV co-infection cases was highest in World Health Organization (WHO) African Region nations, topping $50 \%$ in portions of southern Africa (6). According to the Ethiopia Population-based HIV Impact Assessment (EPHIA), the prevalence of HIV among children aged 0-14 in urban Ethiopia in 2018 was $0.3 \%(9)$.

According to WHO, the prevalence of TB in Ethiopia in 2018 was estimated to be 151/100,000, with a mortality rate of $2 \%$ ranging from 1.4 to $2.8 \%$ among HIV-positive people $(10,11)$. According to WHO, one out of every three HIV-related deaths is caused by tuberculosis (3). It is also the most common opportunistic infection in HIV-positive children, and it is still one of Ethiopia's top ten causes of death (12).

Several comprehensive programs have been designed and implemented to prevent, diagnose, and treat TB among HIV positives. However, the problem remains a major global and national health concern that requires extensive work to reach the SDG and end TB. Even though there have been studies on predictors of mortality in TB/HIV co-infected adults, there have been no previous sufficient scientific investigations 
done on the literature in the pediatric age range, which did not cover some characteristics such as TB medication resistance. Therefore, this study will bridge this information gap and update the previous knowledge on the same problem.

\section{Methods And Materials}

\section{Study design, setting and period}

A hospital-based retrospective cohort study design was used in ART clinics at selected public hospitals in SNNPR, Ethiopia. The study was carried out from February to March 2020 in ART clinics of selected public hospitals in SNNPR. SNNPR is an administrative region in Ethiopia. It is Ethiopia's third-largest administrative region, with nine administrative regions. In terms of culture, language, and ethnicity, it is also the most diverse region in the country. It is divided into 14 zones, one city administration, and four special woredas. Hawassa is its capital city, located 273 kilometers from Addis Ababa, Ethiopia's capital city. According to the 2007 census, the region has an estimated population of 18.9 million people. The region has four referral hospitals and forty general hospitals. The study included six hospitals: three referral (Hawasa University Referral Hospital, Wolaita Sodo University Teaching Referral Hospital, and Nigist Eleni Mohammad Memorial Referral Hospital) and three general (Yirgalem, Arba Minch, and Jinka).

\section{Sample size determination}

The sample size was calculated using the double population proportion formula, with CPT and IPT as the key predictor factors, from a study done in Gondar (13). Then, it was calculated by using Epi info version 7 statistical packages by considering $95 \% \mathrm{Cl}$ and a power of $80 \%$. Additionally, IPT (percent of exposed $\mathrm{P} 1=18.4 \%$, percent of non-exposed $\mathrm{P} 2=6.2 \%$ ) was considered as independent predictor since it gives the maximum sample size. $r$ : is the ratio of non-exposed to exposed 1:1. The largest sample size $(N=288)$ was then chosen as the final sample size for the investigation.

\section{Sampling Procedure}

The study was conducted at selected public hospitals in SNNPR. Purposive sampling was used to select the hospitals with high patient volume. Then, medical record numbers of children who are TB/HIV coinfected and on ART from January 1st, 2009 to December 31, 2019 were identified. The ART log book was used to look for those with history of tuberculosis. Then, since the number of the co-infected children in the selected hospitals was manageable, all of the children who fulfilled the inclusion criteria were included in the study. From 325 identified charts, 284 charts were finally selected. The rest of the charts were excluded due to incompleteness.

\section{Measurement of terms}


ART adherence - classified as Good ( $\geq 95 \%$ or Miss $\leq 3$ doses per month), Fair (85-94\% or Miss $4-8$ doses), and Poor ( $<85 \%$ or Miss $>9$ doses) according to calculated percentage of ART drug taken from the total monthly dosage.

Loss to Follow Up-When the child misses appointment for more than three months

Transferred Out- when a child is transferred to other health facility

Treatment Failure-classified by clinical criteria, immunologic criteria and virologic criteria

Clinical Treatment Failure is the detection of new or recurrent WHO clinical stage of III or IV

Immunologic Treatment Failure is a drop in CD4 level, after the initial immune recovery next to ART initiation to values at or below the age-related CD4 threshold for treatment initiation OR 30\% drop of $\mathrm{CD} 4 \%$ or value from highest levels after therapy.

Virologic Failure -persistent viral load exceeding $5000 \mathrm{copies} / \mathrm{ml}$ in a child who is fully adhered to treatment and who was on ART for at least 24 weeks.

Time to death- the time between the diagnosis of TB/HIV co-infection and occurrence of the event (death) during the follow up period

Censored- If the child is loss to follow up or transferred out before developing the event or if the child is alive at the end of the study period

Drug resistant TB; classified in to Multi drug resistant (MDR), resistance to isoniazid and rifampicin, and Extensive drug resistant (XDR). XDR- resistance to at least four core anti TB drugs involving isoniazid, rifampicin, any of the fluroquinolons like moxifloxacin or levofloxacin and to at least one of the second line drugs which are amicacin, capreomaycin or kanamycin

Immune suppression: classified as severe, advanced, and none or not significant based on WHO classification as shown in Table 1.

\section{Table 1}

Immune suppression-Based on WHO classification 


\begin{tabular}{|c|c|c|c|c|}
\hline \multirow{2}{*}{$\begin{array}{l}\text { HIV-associated } \\
\text { immunodeficiency }\end{array}$} & \multicolumn{4}{|c|}{ Age-related CD4+ values } \\
\hline & $\begin{array}{l}<11 \text { months } \\
\text { (\%CD4+) }\end{array}$ & $\begin{array}{l}12-35 \\
\text { months } \\
\text { (\%CD4+) }\end{array}$ & $\begin{array}{l}36-59 \\
\text { months } \\
\text { (\%CD4+) }\end{array}$ & $\begin{array}{l}>5 \text { years (absolute number } \\
\text { per } \mathrm{mm} 3 \text { or } \% \mathrm{CD} 4+\text { ) }\end{array}$ \\
\hline $\begin{array}{l}\text { None or not } \\
\text { significant }\end{array}$ & $>35$ & $>30$ & $>25$ & $>500$ \\
\hline Mild & $30-35$ & $25-30$ & $20-25$ & $350-499$ \\
\hline Advanced & $25-29$ & $20-24$ & $15-19$ & $200-349$ \\
\hline Severe & $<25$ & $<20$ & $<15$ & $<200$ or $<15 \%$ \\
\hline
\end{tabular}

\section{Data Collection Procedure}

A data extraction tool was developed from the national ART entry and follow up form that is currently used by the ART clinics of the study area. The data was collected by six BSc and five diploma nurses working in the ART clinic of respective hospitals. They used the data collection tool to extract the information from children's charts. Charts were collected by using the children's registration number which is found in the data base in the computer system. In addition, data clerks helped in identifying the charts.

\section{Data quality control}

To maintain the quality of the data, data extraction tool was carefully adapted from the national followup care forms with some modification. One-day training was given regarding the objectives and variables of the study and how to extract data by using the tool was given. Moreover, a periodic supervision took place. In addition, the data extraction tool was pretested to check the consistency.

\section{Data Processing and Analysis}

Before data entry, all questionnaires were checked for completeness. Cleaned and coded data was entered into Epi Data version 4.6 and analysis of the data was conducted by using the statistical package for social sciences (SPSS) version 23. Cox proportional hazard model assumption was checked using Schoenfeld, residual test. Patients' cohort characteristics for continuous data were described in terms of central tendency (mean or median) and dispersion (standard deviation or inter quartile range). Frequency distribution was used for categorical data. The Kaplan Meier survival curve was used to estimate and compare survival time and log rank tests was used to compare survival curves. Bivariate Cox-proportional hazards regression model was fitted for each explanatory variables and multivariable Cox model was used to identify predictors of mortality among TB/HIV co-infected children. Adjusted Hazard Ratio with its 
$95 \%$ confidence interval was used to estimate the strength of association and $p$ value $\leq 0.05$ was considered as statistically significant.

\section{Results}

\section{Socio demographic characteristics}

A total of 325 charts of children on ART and had a history of tuberculosis were reviewed. However, 41 charts were excluded from analysis due to incomplete data. Therefore, 284 charts of children with TB/HIV co-infection were included in the analysis. Among these, almost half $(48.2 \%)$ were male with male to female ratio of $1: 1.07$ and most of the children (47.9\%) were among the age group of 6-10 years. The mean age of the study participants was 7.1(SD \pm 3.7 ) years. Almost one-third $(74.6 \%)$ of the children's care givers were HIV positive. In addition, most of the care givers that is, 133(46.8\%) were among the age group of 25-34 years (Table 2). 
Table 2

Socio-demographic characteristics of TB/HIV co-infected children attending ART clinics of selected public hospitals in SNNPR, Ethiopia, from January 2009 to December 2019

\begin{tabular}{|c|c|c|c|c|c|c|}
\hline \multirow[t]{2}{*}{ Characteristics } & & \multirow[t]{2}{*}{ Total } & \multirow[t]{2}{*}{ Censored } & \multirow[t]{2}{*}{ Death } & \multicolumn{2}{|c|}{ Log Rank test } \\
\hline & & & & & $\mathbf{x}^{2}$ & P-value \\
\hline \multirow[t]{4}{*}{ Age } & $<1$ & $18(6.3)$ & $17(94.4)$ & $1(5.6)$ & \multirow[t]{4}{*}{1.79} & \multirow[t]{4}{*}{0.61} \\
\hline & $1-5$ & $78(27.5)$ & $68(87.2)$ & $10(12.8)$ & & \\
\hline & $6-10$ & $136(47.9)$ & 116(85.3) & $20(14.7)$ & & \\
\hline & $11-15$ & $52(18.3)$ & $48(92.3)$ & $4(7.7)$ & & \\
\hline \multirow[t]{2}{*}{ Sex } & Male & $137(48.2)$ & $121(87.1)$ & 19(12.9) & \multirow[t]{2}{*}{0.00} & \multirow[t]{2}{*}{0.95} \\
\hline & Female & $147(51.8)$ & $128(88.3)$ & 16(11.7) & & \\
\hline \multirow[t]{4}{*}{ Age of care giver } & $15-24$ & $40(14.1)$ & $36(90)$ & $4(10)$ & \multirow[t]{4}{*}{2.70} & \multirow[t]{4}{*}{0.44} \\
\hline & $25-34$ & $133(46.8)$ & 114(85.7) & 19(14.3) & & \\
\hline & $35-44$ & $82(28.9)$ & $74(90.2)$ & $8(9.8)$ & & \\
\hline & $>44$ & $29(10.2)$ & $25(86.2)$ & $4(13.8)$ & & \\
\hline \multirow[t]{4}{*}{ Child lives with } & Parents & $239(84.2)$ & $210(97.9)$ & $29(12.1)$ & \multirow[t]{4}{*}{5.46} & \multirow[t]{4}{*}{0.14} \\
\hline & Guardian & $17(6)$ & $16(94.1)$ & $1(5.9)$ & & \\
\hline & Orphan & $9(3.2)$ & $6(66.7)$ & $3(33.3)$ & & \\
\hline & Others & 19(6.7) & $17(89.5)$ & $2(10.5)$ & & \\
\hline \multirow[t]{5}{*}{ Child care giver } & Mother & $186(65.5)$ & 162(87.1) & $24(12.9)$ & \multirow[t]{5}{*}{2.85} & \multirow[t]{5}{*}{0.58} \\
\hline & Father & $35(12.3)$ & $30(85.7)$ & $5(14.3)$ & & \\
\hline & Step parent & $11(3.9)$ & 10(90.9) & $1(9.1)$ & & \\
\hline & Sibling & $17(6)$ & 17(100) & $0(0)$ & & \\
\hline & Others & $35(12.3)$ & $30(85.7)$ & $5(14.7)$ & & \\
\hline \multirow[t]{3}{*}{ Mother HIV status } & Positive & $223(77.8)$ & 191(85.7) & $32(14.3)$ & \multirow[t]{3}{*}{3.30} & \multirow[t]{3}{*}{0.19} \\
\hline & Negative & $3(1.1)$ & $3(100)$ & $0(0)$ & & \\
\hline & Unknown & $58(20.4)$ & $55(94.8)$ & $3(5.2)$ & & \\
\hline \multirow[t]{3}{*}{ Care giver HIV status } & Positive & $212(74.6)$ & 183(86.3) & $29(13.7)$ & \multirow[t]{3}{*}{2.15} & \multirow[t]{3}{*}{0.34} \\
\hline & Negative & $28(9.9)$ & $27(96.4)$ & $1(3.6)$ & & \\
\hline & Unknown & $44(15.5)$ & $39(88.6)$ & $5(11.4)$ & & \\
\hline
\end{tabular}




\section{Child clinical characteristics}

From the 284 participants, majority of them (91.9\%) had opportunistic infection at baseline. Out of this, pulmonary TB contributes the highest proportion which is, $63 \%$ followed by pneumonia $(17.3 \%)$ and diarrhea (9.9\%). Most (41.2\%) of the children were eligible for HAART by WHO stage criteria. Forty (14.1\%) of the children had treatment failure. Virologic failure taking the highest proportion (22) followed by immunologic failure (11) and clinical failure (7) but only 24 of them were on second line ART drug. On the other hand, $14.8 \%$ of the children had a history of previous TB. Concerning ART drug adherence, $93.7 \%$ of the participants had good adherence in the first three months of ART initiation (Table 3). 
Table 3

Clinical characteristics of TB/HIV co-infected children attending ART clinics of selected public hospitals in SNNPR, Ethiopia, from January 2009 to December 2019

\begin{tabular}{|c|c|c|c|c|c|c|}
\hline \multirow[t]{2}{*}{ Clinical characteristics } & & \multirow[t]{2}{*}{ Total } & \multirow[t]{2}{*}{ Censored } & \multirow[t]{2}{*}{ Dead } & \multicolumn{2}{|c|}{ Log Rank test } \\
\hline & & & & & $\mathbf{X}^{2}$ & $\begin{array}{l}\mathrm{P}- \\
\text { value }\end{array}$ \\
\hline \multirow[t]{2}{*}{ Baseline WHO stage } & $|\&| \mid$ & $60(21.1)$ & 143(96.6) & $5(3.4)$ & \multirow[t]{2}{*}{1.09} & \multirow[t]{2}{*}{0.29} \\
\hline & III \& IV & $224(78.9)$ & 106(77.9) & $30(22.1)$ & & \\
\hline \multirow[t]{4}{*}{ ART eligibility criteria } & CD $4+$ cells & $12(4.2)$ & $12(100)$ & $0(0)$ & \multirow[t]{4}{*}{14.35} & \multirow[t]{4}{*}{0.001} \\
\hline & WHO stage & $117(41.2)$ & 109(93.2) & $8(6.8)$ & & \\
\hline & Both & $78(27.5)$ & $62(79.5)$ & 16(20.5) & & \\
\hline & Not recorded & $77(27.1)$ & $66(85.7)$ & 11(14.3) & & \\
\hline \multirow{2}{*}{$\begin{array}{l}\text { Baseline Opportunistic } \\
\text { infection }\end{array}$} & Yes & 261(91.9) & $229(87.7)$ & $32(12.3)$ & \multirow[t]{2}{*}{0.44} & \multirow[t]{2}{*}{0.50} \\
\hline & No & $23(8.1)$ & $20(87)$ & $3(13)$ & & \\
\hline \multirow[t]{4}{*}{ Initial regimen } & D4T based & 147(51.8) & $129(87.8)$ & 18(12.2) & \multirow[t]{4}{*}{0.66} & \multirow[t]{4}{*}{0.88} \\
\hline & AZT based & 104(36.6) & $90(86.5)$ & 14(13.5) & & \\
\hline & TDF based & $16(5.6)$ & 15(93.8) & $1(6.2)$ & & \\
\hline & $\begin{array}{l}\text { ABC based \& } \\
1 \mathrm{j}\end{array}$ & $17(6)$ & 15(88.2) & $2(11.8)$ & & \\
\hline \multirow[t]{2}{*}{ Initial regimen change } & Yes & $135(47.5)$ & $121(89.6)$ & 14(10.4) & \multirow[t]{2}{*}{1.87} & \multirow[t]{2}{*}{0.17} \\
\hline & No & $149(52.5)$ & $128(85.9)$ & $21(14.1)$ & & \\
\hline \multirow{4}{*}{$\begin{array}{l}\text { Reason for regimen } \\
\text { change }\end{array}$} & Side effect & $33(11.6)$ & $29(87.9)$ & $4(12.1)$ & \multirow[t]{4}{*}{2.6} & \multirow[t]{4}{*}{0.62} \\
\hline & $\begin{array}{l}\text { Treatment } \\
\text { failure }\end{array}$ & $24(8.5)$ & $20(83.3)$ & $4(16.7)$ & & \\
\hline & TB & $30(10.6)$ & $27(90)$ & $3(10)$ & & \\
\hline & Stock out & $35(12.3)$ & $32(91.4)$ & $3(8.6)$ & & \\
\hline \multirow[t]{2}{*}{ Treatment failure } & Yes & $40(14.1)$ & $37(92.5)$ & $3(7.5)$ & \multirow[t]{2}{*}{1.71} & \multirow[t]{2}{*}{0.19} \\
\hline & No & $244(85.9)$ & 212(86.9) & $32(13.5)$ & & \\
\hline \multirow[t]{3}{*}{$\begin{array}{l}\text { Baseline HIV related } \\
\text { immune suppression }\end{array}$} & $\begin{array}{l}\text { Mild/non- } \\
\text { significant }\end{array}$ & $172(60.6)$ & 164(95.3) & $8(4.7)$ & \multirow[t]{3}{*}{33.24} & \multirow[t]{3}{*}{0.001} \\
\hline & Advanced & $46(16.2)$ & $40(87)$ & $6(13)$ & & \\
\hline & Severe & $66(23.2)$ & $45(68.2)$ & 21(31.8) & & \\
\hline
\end{tabular}




\begin{tabular}{|c|c|c|c|c|c|c|}
\hline \multirow[t]{2}{*}{$\mathrm{INH}$} & Yes & $182(64.1)$ & 163(89.6) & 19(10.4) & \multirow[t]{2}{*}{2.24} & \multirow[t]{2}{*}{0.13} \\
\hline & No & 102(35.9) & $86(84.3)$ & $16(15.7)$ & & \\
\hline \multirow[t]{2}{*}{ CPT } & Yes & $260(91.5)$ & 227(87.3) & $33(12.3)$ & \multirow[t]{2}{*}{0.05} & \multirow[t]{2}{*}{0.81} \\
\hline & No & $24(8.5)$ & $22(91.7)$ & $2(8.3)$ & & \\
\hline \multirow[t]{2}{*}{ Baseline hemoglobin } & $\leq 10$ & 104(36.6) & $89(76.7)$ & $27(23.3)$ & \multirow[t]{2}{*}{21.05} & \multirow[t]{2}{*}{0.001} \\
\hline & $>10$ & $180(63.4)$ & 249(95.2) & $35(12.3)$ & & \\
\hline \multirow[t]{2}{*}{ Adherence } & Good & 266(93.7) & 238(89.5) & $28(10.5)$ & \multirow[t]{2}{*}{12.71} & \multirow[t]{2}{*}{0.001} \\
\hline & Fair/poor & $18(6.4)$ & 11(61.1) & 7(38.9) & & \\
\hline \multirow[t]{2}{*}{ Site of TB } & Pulmonary & $218(76.8)$ & $232(90.3)$ & $25(9.7)$ & \multirow[t]{2}{*}{17.59} & \multirow[t]{2}{*}{0.001} \\
\hline & $\begin{array}{l}\text { Extra } \\
\text { pulmonary }\end{array}$ & $66(23.2)$ & $17(63)$ & 10(33) & & \\
\hline \multirow[t]{2}{*}{ Time of TB diagnosis } & Pre ART & $171(60.3)$ & 153(89.5) & 18(10.5) & \multirow[t]{2}{*}{3.65} & \multirow[t]{2}{*}{0.55} \\
\hline & ART & 113(39.8) & $96(85)$ & 17(15) & & \\
\hline \multirow[t]{2}{*}{ Previous history of TB } & Yes & $42(14.8)$ & $29(69)$ & 13(31) & \multirow[t]{2}{*}{19.85} & \multirow[t]{2}{*}{0.001} \\
\hline & No & $242(85.2)$ & $220(90.9)$ & $22(9.1)$ & & \\
\hline \multirow[t]{2}{*}{ TB drug resistance } & No & 264(93) & 237(89.8) & $27(10.2)$ & \multirow[t]{2}{*}{20.29} & \multirow[t]{2}{*}{0.001} \\
\hline & MDR & $20(7)$ & $12(60)$ & $8(40)$ & & \\
\hline
\end{tabular}

\section{Mortality rate}

Two hundred eighty four children with TB/HIV co-infection and on ART follow up were followed for different period of time with total of 1257.17 child-years of observation. They were followed for a minimum of one month to a maximum of 10 years. The median follow up time was 4.5 years. A total of $35(12.3 \%)$ deaths were observed through the follow up time making the overall mortality rate to be 2.78 per 100 person year of follow up $(95 \% \mathrm{Cl}=1.98-3.99)$ for the study cohort. From those who died, $16(45.78 \%)$ of them were male, $60 \%$ of them were WHO stage $4,65.7 \%$ of them had CD 4 level less than two hundred.

The mortality rate of children with extra pulmonary tuberculosis is higher than those with pulmonary Tuberculosis which is 9.6 per 100 child years compared to 2.16 per 100 child years. Moreover, the mortality rate of children with MDR TB (12.53 per 100 child-years) is much higher than those without drug resistant TB (2.26 per 100 child-year) of follow up (Table 4$)$. 
Table 4

Mortality rate stratified by selected socio demographic and clinical characteristics of TB/HIV co-infected children

\begin{tabular}{|c|c|c|c|c|c|}
\hline Characteristics & & Total & NPY & Death & N IDR \\
\hline \multirow[t]{4}{*}{ Age } & $\leq 1$ & $18(6.3)$ & 75.66 & 1 & 1.32 \\
\hline & $1-5$ & $78(27.5)$ & 426.33 & 10 & 2.34 \\
\hline & $6-10$ & $136(47.9)$ & 590.58 & 20 & 3.38 \\
\hline & $11-15$ & $52(18.3)$ & 164.58 & 4 & 2.43 \\
\hline \multirow[t]{2}{*}{ Mother HIV status } & Positive & 219(77.1) & 1028.08 & 32 & 3.11 \\
\hline & Negative/unknown & $65(22.9)$ & 229.08 & 3 & 1.3 \\
\hline \multirow[t]{2}{*}{ Baseline WHO stage } & $|\&| \mid$ & $60(21.1)$ & 212 & 4 & 1.88 \\
\hline & III \& IV & $224(78.9)$ & 1045.166 & 31 & 2.96 \\
\hline \multirow[t]{2}{*}{ Baseline OI } & Yes & 261(91.9) & 1200 & 32 & 2.67 \\
\hline & No & $23(8.1)$ & 57.16 & 3 & 5.24 \\
\hline \multirow[t]{3}{*}{$\begin{array}{l}\text { Baseline HIV related immune } \\
\text { suppression }\end{array}$} & $\begin{array}{l}\text { Non- } \\
\text { significant/mild }\end{array}$ & 172(65.9) & 800.167 & 8 & 9.99 \\
\hline & Advanced & $46(16.1)$ & 196.75 & 6 & 3.04 \\
\hline & Sever & $66(18.1)$ & 260.25 & 21 & 8.06 \\
\hline \multirow[t]{2}{*}{ Hemoglobin level } & $\leq 10$ & 104(36.6) & 455.91 & 27 & 5.92 \\
\hline & $>10$ & $180(63.4)$ & 801.2 & 8 & 0.99 \\
\hline \multirow[t]{2}{*}{ Treatment Failure } & Yes & $40(14.1)$ & 222 & 3 & 1.35 \\
\hline & No & $244(85.9)$ & 1035 & 32 & 3.09 \\
\hline \multirow[t]{2}{*}{ IPT } & Yes & $182(64.1)$ & 874 & 19 & 2.17 \\
\hline & No & $102(35.9)$ & 383.16 & 16 & 4.17 \\
\hline \multirow[t]{2}{*}{ CPT } & Yes & $260(91.5)$ & 11.83 & 33 & 2.8 \\
\hline & No & $24(8.5)$ & 81.3375 & 2 & 2.45 \\
\hline \multirow[t]{2}{*}{ Adherence } & Good & 266(93.7) & 1193.33 & 28 & 2.36 \\
\hline & Fair/poor & $18(6.4)$ & 63.83 & 7 & 10.96 \\
\hline \multirow[t]{2}{*}{ Site of TB } & Pulmonary & $218(76.8)$ & 1153.66 & 25 & 2.16 \\
\hline & Extra pulmonary & $66(23.2)$ & 103.5 & 10 & 9.66 \\
\hline
\end{tabular}




\begin{tabular}{|llllll|}
\hline Characteristics & & Total & N PY & Death & N IDR \\
\hline TB drug Resistance & No & $264(93)$ & 1193.33 & 27 & 2.26 \\
\cline { 2 - 6 } & MDR & $20(7)$ & 63.83 & 8 & 12.53 \\
\hline PY = person year IDR $=$ incidence density rate & & & & \\
\hline
\end{tabular}

\section{Predictors of mortality}

The equality of survival for different categories of explanatory variables was tested by Log rank (MantelCox) test. Hemoglobin level, ART drug adherence, site of TB and TB drug resistance were significantly associated with time to death. The mean survival time of the whole follow-up was 8.8 (95\% Cl; 8.4-9.15) years (Fig. 1).

The mean survival time for those with extra pulmonary tuberculosis was $6.5(95 \% \mathrm{Cl}$ : 4.7-8.2) years whereas it was $9(95 \% \mathrm{Cl}: 8.7-9.4)$ years for those with pulmonary tuberculosis with significance level of $p=0.0001$ (Fig. 2).

The mean survival time of those with multi drug resistant tuberculosis and HIV co-infected is lower 5.5 $(95 \% \mathrm{Cl}: 3.5-7.5)$ years when compared with those with no drug resistances $8.9(95 \% \mathrm{Cl}$ : 8.6-9.3) years ( $\mathrm{p}$ $=0.001)$ (Fig. 3).

The mean survival time for children with hemoglobin level $\leq 10 \mathrm{~g} / \mathrm{dl}$ was $7.73(95 \% \mathrm{Cl}:$ 6.98-8.48) years where as for those who had hemoglobin level above $10 \mathrm{~g} / \mathrm{dl}$ was $9.51(95 \% \mathrm{Cl}: 9.18-9.84)$ years $(\mathrm{p}$ value $=$ 0.001) (Fig. 4).

Individuals who have good ART drug adherence have greater mean survival time than who had fair or poor adherence which was 8.95 (95\% Cl: 8.52-9.31) years compared to 6.28 (95\% Cl: $4.17-8.36)$ years ( $p$ value $=0.001)($ Fig. 5)

\section{Predictors of mortality among TB/HIV co-infected children}

The bivariable Cox regression analysis showed that ART drug adherence, site of TB, previous history of TB, time of TB diagnosis, WHO stage at TB, drug resistant TB, Hemoglobin level at baseline, Isoniazid prophylaxis (IPT), presence of Pulmonary TB, extra pulmonary TB, oral and esophageal thrush at baseline, and adherence to ARV drugs were associated with mortality of TB/HIV co-infected children. But site of TB, drug resistant TB, hemoglobin level and ART drug adherence remained statistically significant predictors of mortality among TB/HIV co-infected children in multivariable Cox-regression analysis.

According to this study, the hazard of dying for TB/HIV co-infected children with hemoglobin level of $<10$ $\mathrm{gm} / \mathrm{dl}$ was higher than those with hemoglobin level of $>10 \mathrm{gm} / \mathrm{dl}$ (AHR $=3.6 ; 95 \% \mathrm{Cl}: 1.39-9.31$ ).

Individuals who had drug resistant TB have 5.7 times higher hazard of dying than those who had no drug resistant TB (AHR $=5.7 ; 95 \% \mathrm{Cl}: 2.07-15.96)$. Children who had good adherence had 2.9 times higher 
hazard of dying than those with fair or poor adherence $(A H R=2.9 ; 95 \% \mathrm{Cl}=1.15-7.43)$. Moreover, those children with extra pulmonary TB have 3.9 times higher hazard of dying than those with pulmonary TB (AHR $=3.9 ; 95 \% \mathrm{Cl}: 1.34-11.45)$ (Table 5). 
Table 5

Cox-regression analysis of predictors of mortality of TB/HIV co-infected children attending ART clinics of public hospitals in SNNPR, Ethiopia from January 2009 to December 2019

\begin{tabular}{|c|c|c|c|c|c|}
\hline Variables & Categories & Death & Censored & CHR & AHR \\
\hline \multirow[t]{2}{*}{ Time of TB diagnosis } & Pre ART & 18 & 153 & $\begin{array}{l}0.52(0.26- \\
1.03)\end{array}$ & $\begin{array}{l}0.5(0.18- \\
1.36)\end{array}$ \\
\hline & ART & 17 & 96 & 1 & 1 \\
\hline \multirow{2}{*}{$\begin{array}{l}\text { WHO stage at TB } \\
\text { diagnosis }\end{array}$} & III & 14 & 169 & 1 & 1 \\
\hline & IV & 21 & 80 & $\begin{array}{l}3.0(1.53- \\
5.95)\end{array}$ & $\begin{array}{l}1.61(0.71- \\
3.67)\end{array}$ \\
\hline \multirow[t]{2}{*}{ Hemoglobin level } & $\leq 10 \mathrm{mg} / \mathrm{dl}$ & 27 & 89 & $\begin{array}{l}5.23(2.37- \\
11.54)\end{array}$ & $\begin{array}{l}3.6(1.39- \\
9.31)^{\star}\end{array}$ \\
\hline & $>10 \mathrm{mg} / \mathrm{dl}$ & 8 & 160 & 1 & 1 \\
\hline \multirow[t]{2}{*}{ Site of TB } & Pulmonary & 25 & 232 & 1 & 1 \\
\hline & $\begin{array}{l}\text { Extra } \\
\text { pulmonary }\end{array}$ & 10 & 17 & $\begin{array}{l}4.2(2.02- \\
8.81)\end{array}$ & $\begin{array}{l}3.9(1.34- \\
11.45)^{\star}\end{array}$ \\
\hline \multirow[t]{2}{*}{ TB drug resistance } & No & 27 & 237 & 1 & 1 \\
\hline & MDR & 8 & 12 & $\begin{array}{l}5.1(2.31- \\
11.31)\end{array}$ & $\begin{array}{l}5.7(2.07- \\
15.96)^{\star}\end{array}$ \\
\hline \multirow[t]{2}{*}{ ART drug adherence } & Good & 28 & 238 & 1 & 1 \\
\hline & Fair/Poor & 7 & 11 & $\begin{array}{l}4.02(1.75- \\
9.22)\end{array}$ & $\begin{array}{l}2.9(1.15- \\
7.43)^{\star}\end{array}$ \\
\hline \multirow[t]{2}{*}{ Previous history of TB } & Yes & 14 & 53 & $4.1(2-8.33)$ & $\begin{array}{l}2.63(1.07- \\
6.44)\end{array}$ \\
\hline & No & 21 & 196 & 1 & 1 \\
\hline \multirow[t]{2}{*}{ ART treatment failure } & Yes & 3 & 37 & $\begin{array}{l}0.46(0.14- \\
1.5)\end{array}$ & $\begin{array}{l}0.56(0.16- \\
1.93)\end{array}$ \\
\hline & No & 212 & 32 & 1 & 1 \\
\hline \multirow[t]{2}{*}{ IPT } & Yes & 19 & 163 & 1 & 1 \\
\hline & No & 16 & 86 & $\begin{array}{l}1.65(0.85- \\
3.22)\end{array}$ & $\begin{array}{l}0.55(0.26- \\
1.15)\end{array}$ \\
\hline \multirow[t]{2}{*}{ Baseline PTB } & Yes & 20 & 159 & $\begin{array}{l}0.55(0.27- \\
1.14)\end{array}$ & $\begin{array}{l}2.3(0.66- \\
8.17)\end{array}$ \\
\hline & No & 15 & 90 & 1 & 1 \\
\hline
\end{tabular}

$\mathrm{CHR}=$ crude hazard ratio, $\mathrm{AHR}=$ adjusted hazard ratio, *significantly associated variables with $\mathrm{P}<$ 0.05 


\begin{tabular}{|c|c|c|c|c|c|}
\hline Variables & Categories & Death & Censored & CHR & AHR \\
\hline \multirow[t]{2}{*}{ Baseline EPTB } & Yes & 4 & 13 & $2.3(0.8-6.5)$ & $\begin{array}{l}0.97(0.24- \\
3.9)\end{array}$ \\
\hline & No & 31 & 236 & 1 & 1 \\
\hline \multirow[t]{2}{*}{ Baseline oral thrush } & Yes & 3 & 11 & $\begin{array}{l}2.44(0.74- \\
8.01)\end{array}$ & $\begin{array}{l}3.7(1.02- \\
13.39)\end{array}$ \\
\hline & No & 32 & 238 & 1 & 1 \\
\hline \multirow[t]{2}{*}{$\begin{array}{l}\text { Baseline esophageal } \\
\text { thrush }\end{array}$} & Yes & 2 & 6 & $\begin{array}{l}3.3(0.79- \\
13.93)\end{array}$ & $\begin{array}{l}4.4(0.77- \\
25.02)\end{array}$ \\
\hline & No & 33 & 243 & 1 & 1 \\
\hline
\end{tabular}

\section{Discussion}

The mortality rate of children with TB/HIV co-infection was 2.78 per 100 child years of follow up and the proportion of mortality was $12.3 \%$ within the study population. The rate of mortality is slightly lower than a cohort study conducted in Gondar (13). The reason for this might be because the previous study was conducted over twelve years of period which is longer than the study period of this study. Moreover, this finding is lower than cohort study conducted in South Africa (14). This may be explained by the fact that the previous study was conducted only on children younger than two years of age. This age group is high risk group because of immature immune system leading to severe disease and death.

Additionally, according to the study, one third of the study participants had TB before ART was initiated for them. This may also contribute to death because the presence of TB may further weaken the immune system leading to increased viral load which results in severe immune suppression. On the other hand, this result is a little higher than a study conducted in Nigeria (15). This may be explained by the previous study did not include children who were co-infected with extra pulmonary tuberculosis. These children are at a greater risk of mortality due to the severity of the disease. Therefore, the inclusion of extra pulmonary TB and HIV co-infected children in this study might be the reason for higher mortality rate.

The proportion of mortality in this study which is $12.3 \%$ is concordant to the studies done in Tanzania (16), Nigeria (17), Malawi (18), South Africa (19), meta-analysis in South Africa (20) and Uganda (21). Furthermore, only slight difference from an observational cohort study conducted in four countries (22) and South Africa (23). This may be due to the similarities in the burden of HIV, TB and HIV/TB coinfection as all study areas are classified under high burden countries and the similarities in the age group of study participants may be another reason. However, the finding was lower from studies done in 
Thailand (24), India (25) and Congo (26). This difference is may be due to the difference in number of study participants from the study in Thailand. Furthermore, the studies from India and South Africa were conducted only on MDR TB/HIV co-infected children who are at high risk of mortality.

According to this study, the overall cumulative survival time of the study period was $76.1 \%$ which is comparable with study conducted in Gondar (13). This is may be because of the similarities in study participant's age, socio demographic characteristics and management protocols of TB, HIV and TB/HIV co-infection. The pick mortality rate in this study, which is 12.1 per 100 child-years, was observed in the first six months of follow up. The possible reason for this may be the immune reconstitution inflammatory syndrome (IRIS) which is in general abnormal immune response to antigens after the initiation of ART drugs mostly in the first six months of initiation.

The study indicates that, children who had severe anemia had higher hazard of mortality than those who had no severe anemia which was in line with studies conducted in Gondar, Tanzania and Thailand (13, $16,27)$. The possible justification could be, low hemoglobin level in anemic children leads to decreased oxygen delivery to cells which hinders the cells ability to maintain and repair its self. This condition will add burden on the TB/HIV co-infected child leading to mortality.

The extra pulmonary tuberculosis among TB/HIV co-infected children was four times more hazard of dying than those who are co-infected with pulmonary tuberculosis. Similar finding was reported by the study from Gondar comprehensive specialized hospital(13). This may be due to the extra pulmonary forms of TB are mostly more severe than pulmonary TB. It may also affect multiple organs at the same time in the case of disseminated tuberculosis increasing the chance of death of the children who are already weakened by the HIV virus.

Additional factor that resulted from the analysis of this study was ART drug adherence. The children who had fair or poor drug adherence were 2.9 times more hazard of mortality than those with good ART drug adherence. This result is in line with a study conducted in India(25). This may be because ART drugs have role in viral suppression which decreases the viral load helping the immune system to recover. Therefore, children with good adherence have better ability to fight the co-infection. But those who have fair or poor drug adherence may end up with treatment failure speeding up the viral replication thus leading to weakened immunity and death.

Furthermore, individuals co-infected with MDR TB and HIV had 5.7 times higher risk of mortality than children co-infected with non-drug resistant TB and HIV which is in line with the result of this study(28). The reason for this can be, the treatment challenges that are experienced during treating the drug resistant strains that require second line regimens which have more adverse effects than the first line anti tuberculosis drugs affecting the co-infected child synergistically with the ART drugs. Moreover, as the treatment requires longer period than the non-drug resistant TB, it increases the children's risk by exposing them for longer period.

\section{Limitation of the study}


Since this study was conducted based on secondary data, charts excluded due to incomplete data and lost charts which may be related to mortality might underestimate the result of the study. The poor management of charts of children who died will also negatively affect the result. On the other hand, since TB is not recorded on most of the ART registers, it makes it difficult to find charts of all TB/HIV coinfected children on the study period which also affect the outcome. Lastly, the difficulties to diagnose tuberculosis among pediatrics will probably have effect on the result.

\section{Conclusion}

Mortality rate of TB/HIV co-infected children in selected public hospitals in SNNPR, Ethiopia was documented as 2.78 per child years of observation as a result of this study. Moreover, Anemia, drug resistant tuberculosis, extra pulmonary TB and poor adherence to ART drugs were identified as the predictors of mortality among these children. The governmental and non- governmental organizations should provide trainings concerning screening, diagnosis and management of TB/HIV co-infection in children to health care providers. Prospective cohort study will be suggested on mortality among TB/HIV co-infected children in order to fill the gap of incomplete data.

\section{Abbreviations}

ABC Abacavir, AHR Adjusted Hazard Ratio, ART Antiretroviral Therapy, AZT Zidovudine, CD4 Cluster for Differentiation 4, CPT Cotrimoxazole Prophylaxis Therapy, CHR Crude Hazard Ratio, D4T Stavudine, EFV Efavirenz, Hgb Hemoglobin, HIV Human immune virus, IPT Isoniazid Prophylaxis Therapy, IRIS Immune reconstitution Inflammatory syndrome, MDR-TB Multi-drug resistant tuberculosis, 3TC Lamivudine, NVP Nevirapine, Ols Opportunistic Infections, SDG Sustainable developmental goal, SD Standard Deviation, SNNPR Southern Nation Nationalities and Peoples Region, TB Tuberculosis, TDF Tenofovir, UNAIDS United Nations Program on HIV/AIDS, WAZ Weight for age Z

\section{Declarations}

\section{Ethics approval and consent to participate}

Ethical approval was obtained from Institutional Review board of Addis Ababa University, College of Health sciences, School of Nursing and Midwifery. Permission to conduct the study was acquired from Zonal and District Health offices. A formal letter was submitted to the respective hospitals. Since the study was done through reviewing of medical records, the individual patients may not be harmed as long as the confidentiality is kept. Confidentiality was kept by coding all the collected data. Moreover, the charts were locked in a separate room before it was entered in to the computer. After entering the data, the computer was locked by password. Names and unique ART numbers were not included in data collection format and the data was not disclosed to any person other than principal investigator. All 
information collected from patients' cards was kept strictly confidential and names of patients on ART were not included in the checklist.

\section{Consent for publication}

Not applicable

\section{Availability of data and material}

All relevant data are within the paper but any additional data required by the journal can be available anytime.

\section{Competing Interests:}

All Authors declare that they have no competing interest.

\section{Funding}

This study was financially supported by the Addis Ababa University. The sponsors had no role in data collection, analysis of the data, writing of the report or the decision to submit for publication.

\section{Authors' contributions}

JG drafted the proposal, did the analysis, wrote the results, and prepared the manuscript. BG, TT, AS and DE participated in editing, analysis, and write up of the result. All authors made substantial contribution to the work reported, whether that is in the conception, study design, execution, acquisition of data, analysis, and interpretation. All authors have read and approved the final manuscript.

\section{Acknowledgment}

We would like to thank Addis Ababa University. We are also grateful to the zonal and district health offices, six hospitals in SNNPR for allowing us to conduct my research. Our gratitude goes to supervisors, data collectors, and study respondents for facilitating the study.

\section{References}

1. Panamerican Health Organization. TB/HIV Coinfection. Regional Clinical Manual. 2017. 122 p. 
2. Kliegman RM. Nelson text book of pediatrics. 20th ed. Richa, editor. Philadelphia; 2016. 1445-1460 p.

3. Key facts. 2019;2019.

4. EMPHASIS ON AFRICA *. Quality and Coverage of HIV Sentinel Surveillance With a brief History of the HIV / AIDS Epidemic. 2003;(September):8-13.

5. Narendran G, Swaminathan S. TB-HIV co-infection: A catastrophic comradeship. Oral Dis. 2016;22:46-52.

6. WHO. Global Tuberculosis report. 2019.

7. Turkova A, Chappell E, Judd A, Goodall RL, Welch SB, Foster C, et al. Prevalence, incidence, and associated risk factors of tuberculosis in children with HIV living in the UK and Ireland (CHIPS): a cohort study. Lancet HIV. 2015;2(12):e530-9.

8. UNAIDS. 2018 Global HIV Statistics. Unaids. 2019;1-6.

9. Impact PHIV, Ephia A. ETHIOPIA POPULATION-BASED HIV IMPACT ASSESSMENT. EPHIA 20172018. 2018;(April):4-7.

10. WHO. Roadmap towards ending TB in children and adolescents. 2018.

11. WHO. Global Tuberculosis Report. Vol. 1: Geneva; 2019.

12. Institute TEP health. Report on National TB / HIV Sentinel Surveillance. Addis Ababa; 2015.

13. Atalell KA, Tebeje NB, Ekubagewargies DT. Survival and predictors of mortality among children coinfected with tuberculosis and human immunodeficiency virus at University of Gondar Comprehensive Specialized Hospital, Northwest Ethiopia. A retrospective follow-up study. 2018;112.

14. Walters E, Duvenhage J, Draper HR, Hesseling AC, Wyk SS, Van, Cotton MF, et al. Severe manifestations of extrapulmonary tuberculosis in HIV-infected children initiating antiretroviral therapy before 2 years of age. 2014.

15. Ebonyi AO, Oguche S, Agbaji OO, Sagay AS, Okonkwo PI, Idoko JA, et al. Original article Mortality among pulmonary tuberculosis and HIV-1 co-infected Nigerian children being treated for pulmonary tuberculosis and on antiretroviral therapy: a retrospective cohort study. 2016;6(December):139-50.

16. Mwiru RS, Spiegelman D, Duggan C, lii GRS, Semu H, Chalamilla G, et al. Nutritional Status and Other Baseline Predictors of Mortality among HIV-Infected Children Initiating Antiretroviral Therapy in Tanzania. 2015;14(2):172-9.

17. Adejumo OA, Daniel OJ, Adebayo BI, Adejumo EN, Jaiyesimi EO, Akang G, et al. Treatment outcomes of childhood TB in lagos, Nigeria. J Trop Pediatr. 2016;62(2):131-8.

18. Buck WC, Olson D, Kabue MM, Ahmed S, Nchama LK, Munthali A, et al. Risk factors for mortality in Malawian children with human immunodeficiency virus and tuberculosis co-infection. Int J Tuberc Lung Dis. 2013;17(11):1389-95.

19. Hicks RM, Padayatchi N, Shah NS, Wolf A, Werner L, Sunkari VB, et al. Malnutrition associated with unfavorable outcome and death among South African MDR-TB and HIV co-infected children. Int J 
Tuberc Lung Dis. 2014;18(9):1074-9.

20. Isaakidis P, Casas EC, Das M, Tseretopoulou X, Ntzani EE, Ford N. Treatment outcomes for HIV and MDR-TB co-infected adults and children: systematic review and meta-analysis. 2015;19(March):969-78.

21. Bakeera-Kitaka S, Conesa-Botella A, Dhabangi A, Maganda A, Kekitiinwa A, Colebunders R, et al. Tuberculosis in human immunodeficiency virus infected Ugandan children starting on antiretroviral therapy. Int J Tuberc Lung Dis. 2011;15(8):1082-6.

22. Marcy O, Tejiokem M, Msellati P, Truong Huu K, Do Chau V, Tran Ngoc D, et al. Mortality and its determinants in antiretroviral treatment-naive HIV-infected children with suspected tuberculosis: an observational cohort study. Lancet HIV. 2018;5(2):e87-95.

23. Du QT, Renner L, Reubenson G. Tuberculosis treatment outcomes among HIV/TB co-infected children in the international epidimology databases to evaluate AIDS (leDEA) network. HHS Public Access. 2018;(2).

24. Salvadori N, Ngo-giang-huong N, Duclercq C, Kanjanavanit S, Ngampiyaskul C, Techakunakorn P, et al. Incidence of Tuberculosis and Associated Mortality in a Cohort of Human Immunodeficiency Virus-Infected Children Initiating Antiretroviral Therapy. 2018;6(January):161-7.

25. Isaakidis P, Cox HS, Varghese B, Montaldo C, Silva E, Da, Ladomirska J, et al. Ambulatory Multi-Drug Resistant Tuberculosis Treatment Outcomes in a Cohort of HIV-Infected Patients in a Slum Setting in Mumbai. India. 2011;6(12):1-9.

26. Mukuku O, Augustin Mulangu Mutombo, Kakisingi CN, Musung JM, Wembonyama SO, Luboya ON. Tuberculosis and HIV co-infection in Congolese children: risk factors of death. Pan Afr Med J. 2019;8688:1-9.

27. Salvadori N, Ngo-giang-huong N, Duclercq C, Kanjanavanit S, Ngampiyaskul C, Techakunakorn P, et al. Incidence of Tuberculosis and Associated Mortality in a Cohort of Human Immunodeficiency Virus-Infected Children Initiating Antiretroviral Therapy. 2017;6:161-7.

28. Salvadori N, Ngo-giang-huong N, Duclercq C, Kanjanavanit S, Ngampiyaskul C, Techakunakorn P, et al. Incidence of Tuberculosis and Associated Mortality in a Cohort of Human Immunodeficiency Virus-Infected Children Initiating Antiretroviral Therapy. 2017;6:161-7.

\section{Figures}




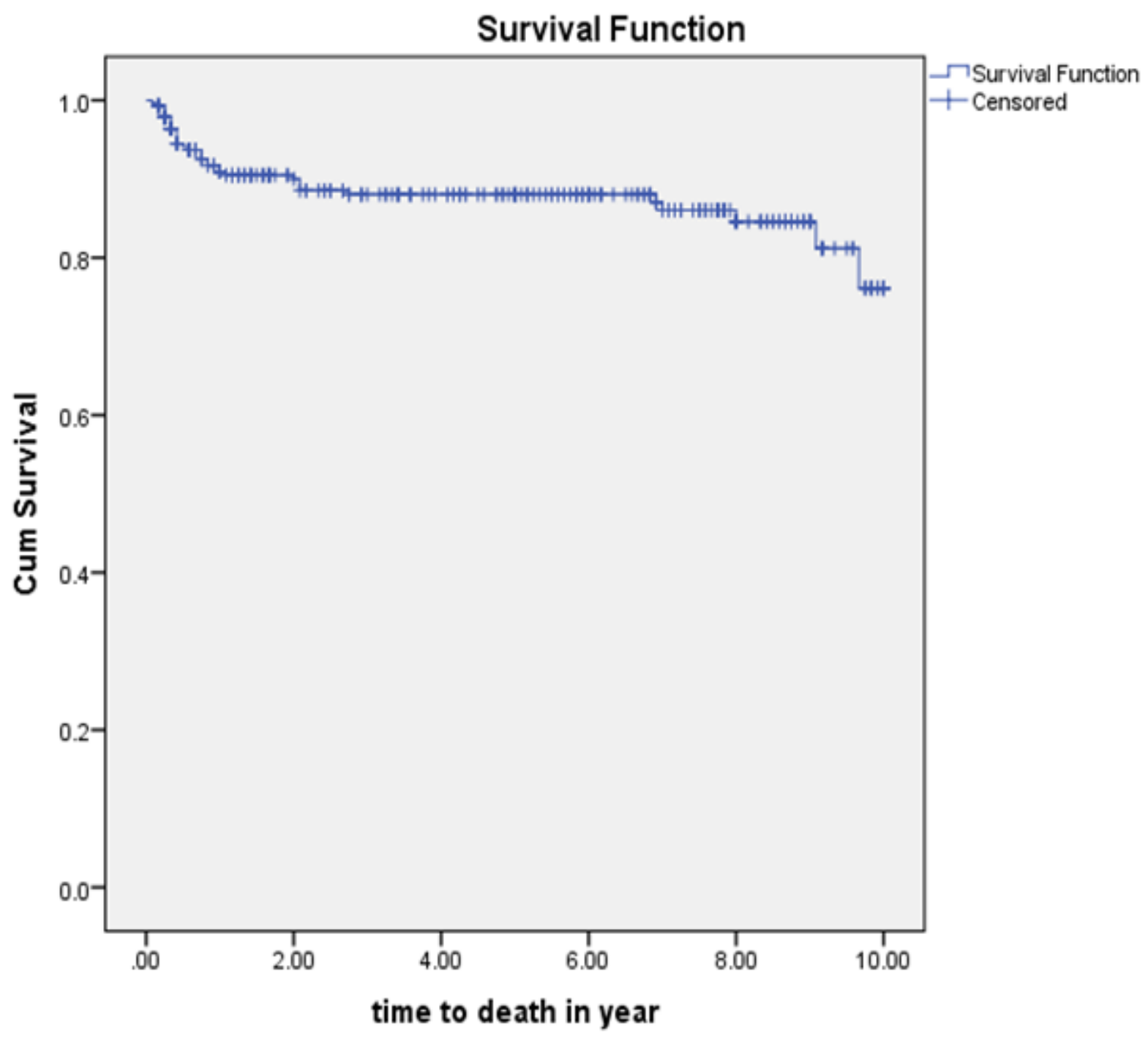

Figure 1

Kaplan-Meier curve of survival proportion for TB/HIV co-infected children attending ART clinics of selected public hospitals in SNNPR, Ethiopia, from January 2009 to December 2019 


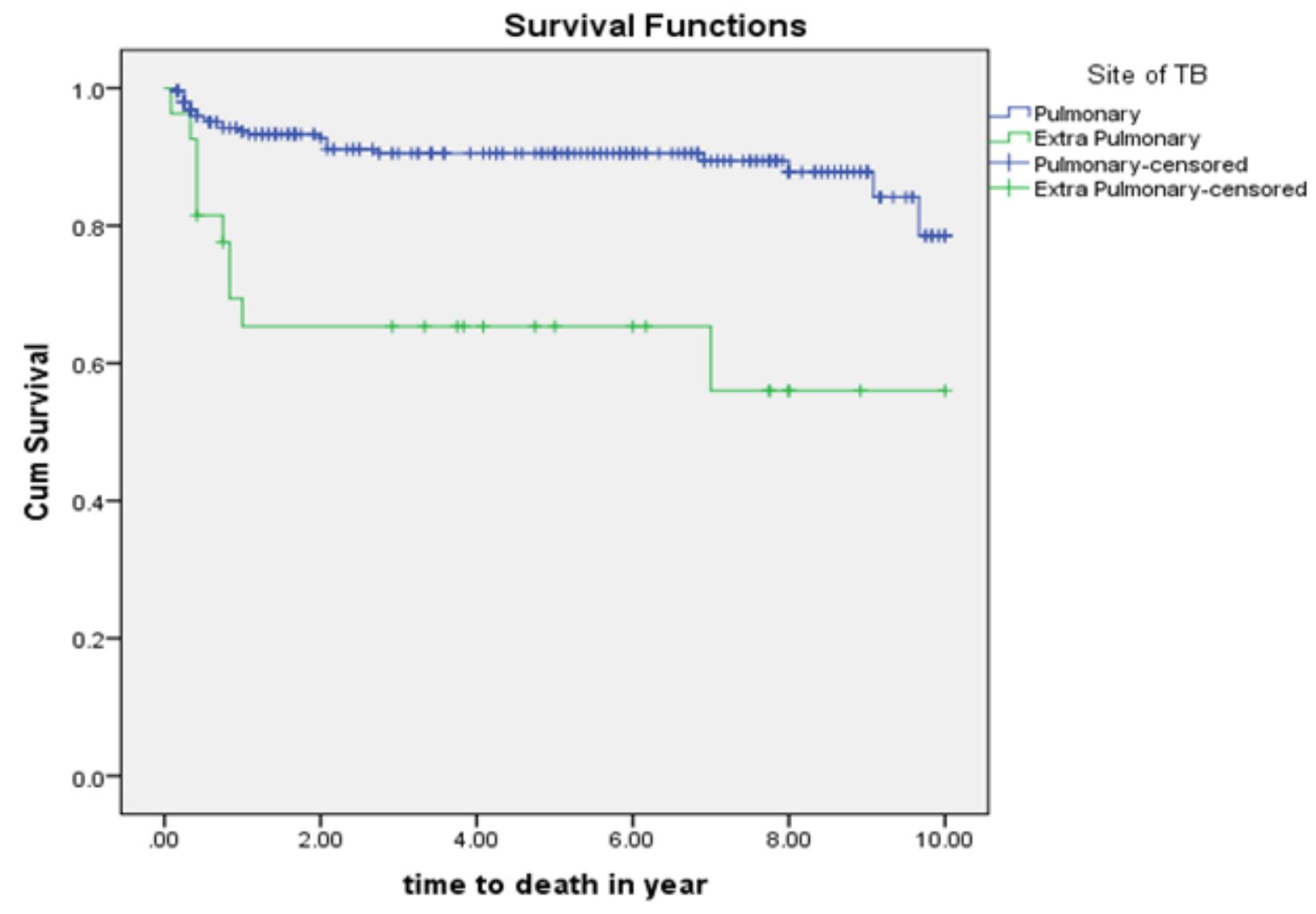

Figure 2

The Kaplan- Meier estimates of survival function by site of TB infection of TB/HIV co-infected children attending ART clinics of selected public hospitals in SNNPR, Ethiopia from January 2009 to December 2019 


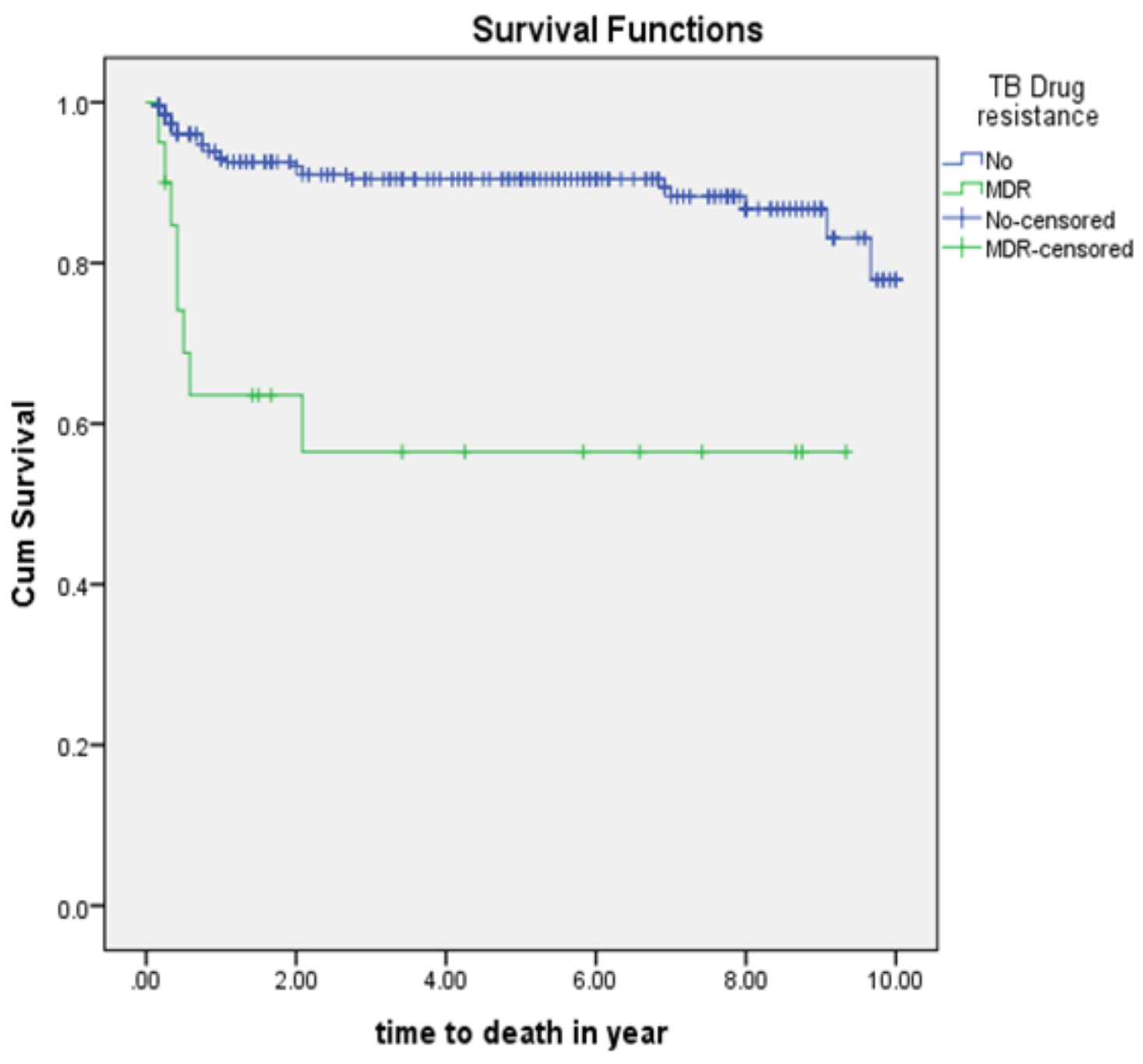

\section{Figure 3}

The Kaplan- Meier estimates of survival function by TB drug resistance status of TB/HIV co-infected children attending ART clinics of selected public hospitals in SNNPR, Ethiopia from January 2009 to December 2019 


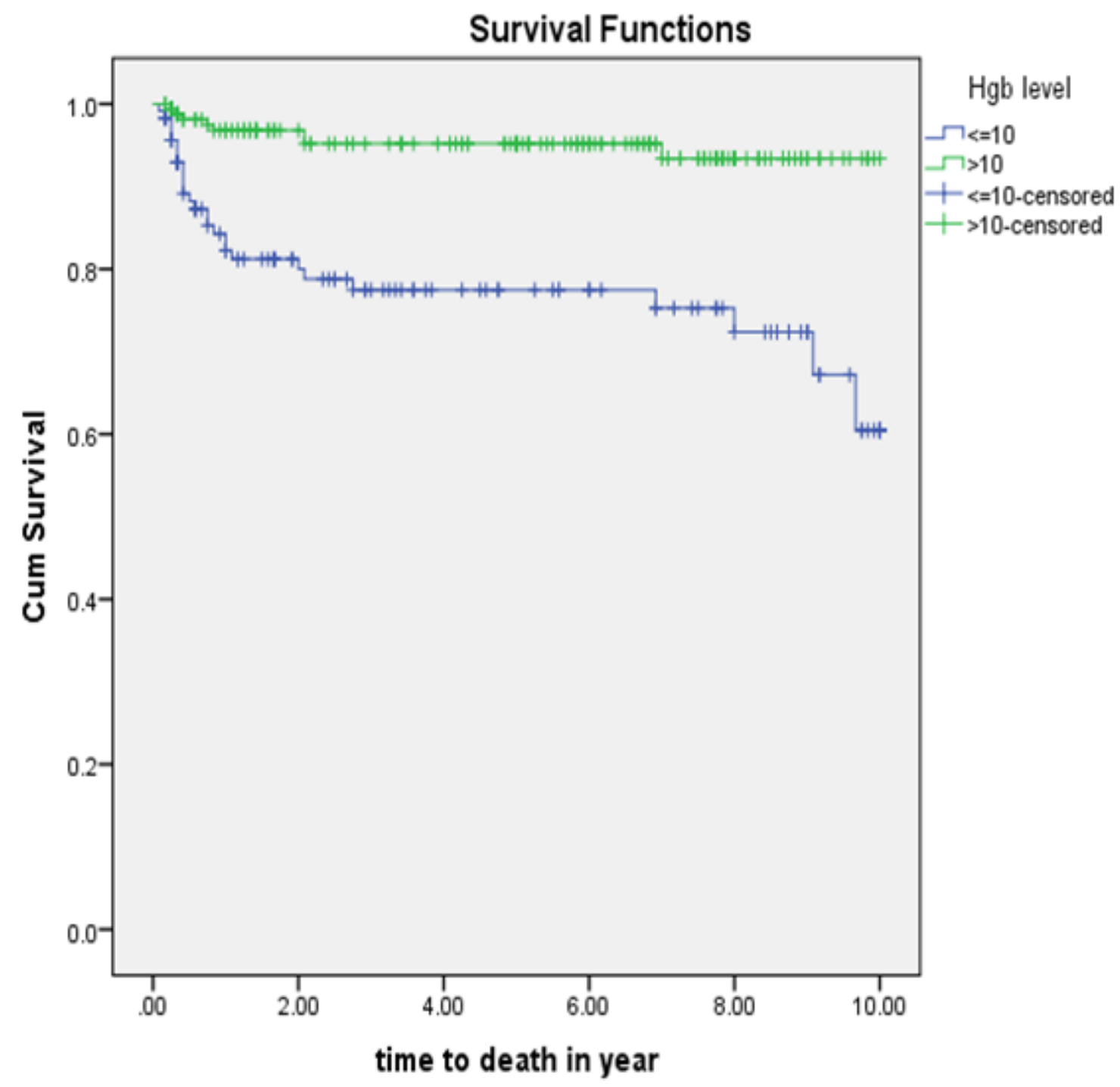

Figure 4

Kaplan - Meier survival curve of hemoglobin level of TB/HIV co-infected children attending ART clinics of selected public hospitals in SNNPR, Ethiopia from January 2009 to December 2019 


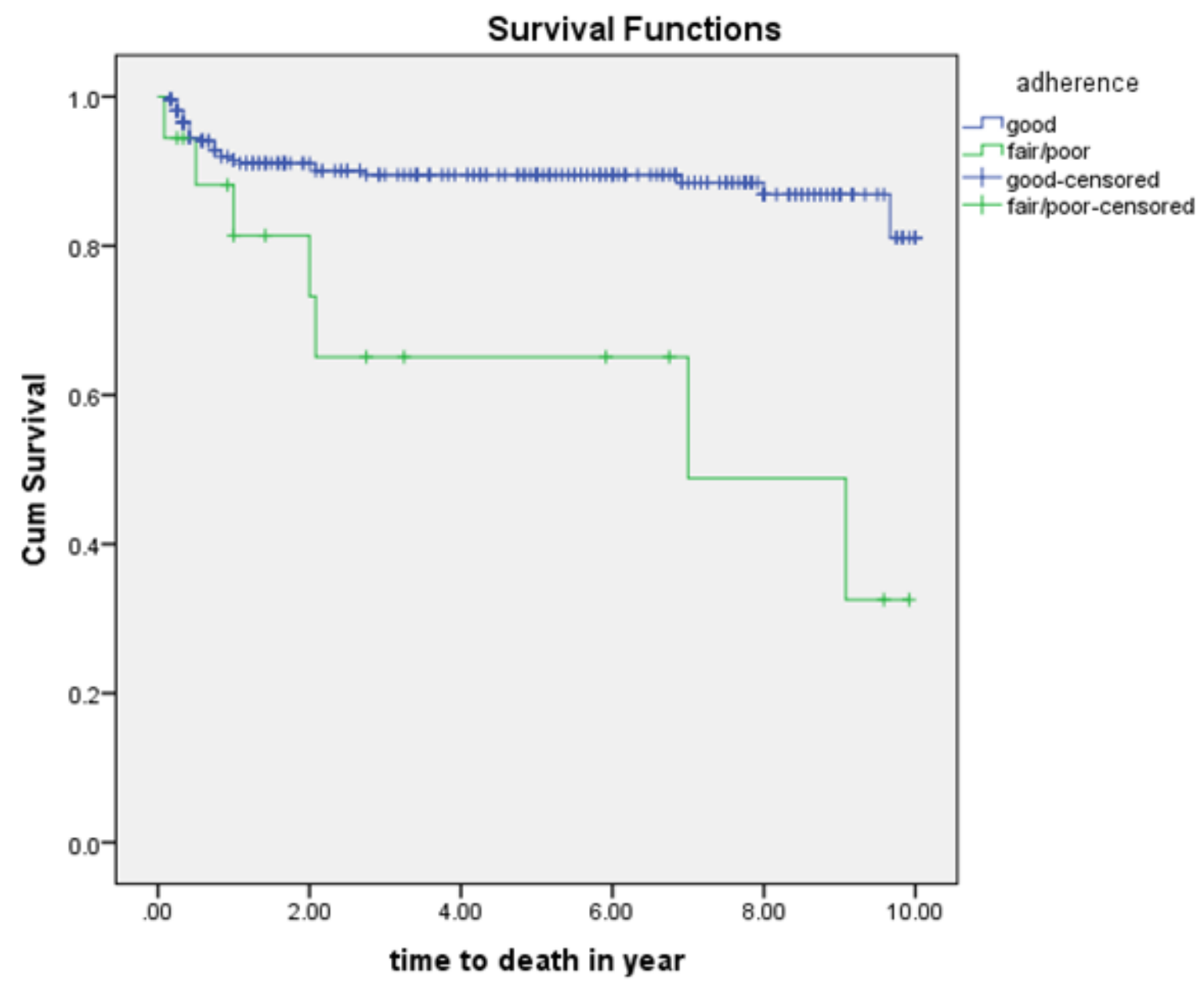

\section{Figure 5}

The Kaplan- Meier estimates of survival function by ART drug adherence of TB/HIV co-infected children attending ART clinics of selected public hospitals in SNNPR, Ethiopia from January 2009 to December 2019. 